\title{
The Influence of Investor Intrinsic Motivation on Islamic Stock Investment Decision Making
}

\author{
Fitria Husnatarina ${ }^{1, *}$, Muh. Arafah ${ }^{2}$, Andiyan Andiyan $^{3}$, Zul Azmi ${ }^{4}$, Yenny Suzana ${ }^{5}$, \\ Andi Hartati ${ }^{6}$
}

${ }^{1}$ Palangka Raya University, Indonesia

${ }^{2}$ IAIN Bone, Indonesia

${ }^{3}$ Universitas Faletehan, Indonesia

${ }^{4}$ Universitas Muhammadiyah Riau, Indonesia

${ }^{5}$ IAIN Langsa, Indonesia

${ }^{6}$ Tompotika University, Indonesia

${ }^{*}$ Corresponding author. Email: fitria.husnatarina@feb.upr.ac.id

\begin{abstract}
This study examines the effect of investor intrinsic motivation variables, option, competence, full of meaning, and Progress on Islamic stocks investment decision making in the Indonesia Stock Exchange. The sample in this study is the investors of Islamic stocks in Central Kalimantan, who come from the Investor Community of Central Kalimantan. The sampling method used is purposive sampling. The questionnaire survey is used to assess investors' choice of Islamic stocks, which are influenced by the personal attributes of the research sample's investors. The questionnaires were distributed as many as 100 questionnaires with a return rate of 82 questionnaires or equal to $82 \%$. This study uses a regression analysis that is used multiple regression analysis. This study indicates that all of the intrinsic motivation attributes of option, competence, full of meaning, and Progress positively and significantly affect investment decisionmaking for investors in Islamic stocks. The implication of this research is expected to contribute to a strategy in literacy development associated with a personal approach through understanding the intrinsic Motivation of investors by prioritizing the benefits of investing in Islamic stocks on the Indonesia Stock Exchange.
\end{abstract}

Keywords: option, competence, full of meaning, Progress, investors, decision making, Islamic stocks.

\section{INTRODUCTION}

Although behavioral finance is a relatively new area, it has been investigated over the years. Behavioral finance developed in response to the needs of the corporate and academic worlds, which started to expose behavioral features or factors in the process of financial and investment decision-making [1]. More precisely, behavioral finance seeks to address the questions of what, why, and how money and investing work from a human perspective [2]. It takes into account human behavior in finance. Behavioral finance is described as the study of the psychological influences on the conduct of financial practitioners. Individuals' choices about purchasing tiny quantities of securities from individual accounts influence their decision-making [3].

Individual investors' investing decisions have become necessary in the modern era due to the opportunity for a better lifestyle and financial independence [4]. Not all investment decisions are reasonable [5]. Behavioral finance theory elucidates investor irrationality and decision-making processes via cognitive psychology and cognitive biases connected with individual beliefs and preferences. In terms of investing, it seems as if most individuals make investment choices based on their emotions, feelings, fantasies, moods, and sentiments, all of which eventually affect investment decisions [3].

Individual investors participate in very modest transactions. Individual investors' investing behaviors differ significantly due to various variables affecting their rationality, including personal motivation, financial and environmental factors influencing each investor's investment choices [6].

According to [7] in [8], Motivation is a desire that compels someone to act. Thus, Motivation is a driving force that motivates individuals to work or act intentionally. Personal Motivation is the act of encouraging someone to direct and sustain work-related behavior. 
Thomas in [9] created a model of intrinsic Motivation. This theory identifies the primary factors contributing to an individual's intrinsic Motivation. This idea explains why genuinely driven individuals seek more effective methods to get strength and happiness from successfully performing something. [10] in [8] According to this definition, intrinsic Motivation is an urge that comes from inside a person when he engages in activities for his benefit and derives pleasure and satisfaction from his actions. The constituents of [10] The following is a description of the intrinsic motivation model:

a. Choice refers to the ability to complete practical task tasks successfully.

b. Competence is the perceived accomplishment of doing things with a high level of expertise.

c. Meaningful is the chance to work toward a worthwhile objective, the objective of which is the more excellent plan.

Table 1. Decription Of Respondents' Intrinsic Motivation Variables

\begin{tabular}{|c|c|c|c|c|c|c|c|c|c|c|c|}
\hline \multirow{3}{*}{$\begin{array}{l}\text { Variable } \\
\text { Indicators }\end{array}$} & \multicolumn{10}{|c|}{ Respondents' Answers Frequency (\%) } & \multirow{3}{*}{\begin{tabular}{|c|} 
Aver \\
age \\
Scor \\
e \\
\end{tabular}} \\
\hline & \multicolumn{2}{|c|}{ STS (1) } & \multicolumn{2}{|c|}{ ST (2) } & \multicolumn{2}{|c|}{ CS (3) } & \multicolumn{2}{|c|}{ S (4) } & \multicolumn{2}{|c|}{ SS (5) } & \\
\hline & f & $\%$ & & $\%$ & & $\%$ & & $\%$ & & $\%$ & \\
\hline X1.1 & 3 & 4,5 & 1 & 1,5 & 13 & 19,7 & 36 & 54,5 & 13 & 19,7 & 3,83 \\
\hline $\mathrm{X} 1.2$ & 7 & 10,6 & 9 & 13,6 & 13 & 19,7 & 27 & 40,9 & 10 & 15,2 & 3,36 \\
\hline $\mathrm{X} 1.3$ & 3 & 4,5 & 4 & 6,1 & 9 & 13,6 & 39 & 59,1 & 11 & 16,7 & 3,77 \\
\hline$\sum \mathrm{X} 1$ & 13 & 19,6 & 14 & 21,2 & 35 & 53 & 102 & $\begin{array}{c}154, \\
5\end{array}$ & 34 & 51,6 & \\
\hline Option & 4 & 6,5 & 5 & 7,1 & 12 & 17,7 & 34 & 51,5 & 11 & 17,2 & 3,7 \\
\hline X2.1 & 2 & 3,0 & 13 & 19,7 & 14 & 21,2 & 27 & 40,9 & 10 & 15,2 & 3,45 \\
\hline $\mathrm{X} 2.2$ & 5 & 7,6 & 11 & 16,7 & 22 & 33,3 & 21 & 31,8 & 7 & 10,6 & 3,21 \\
\hline $\mathrm{X} 2.3$ & 3 & 4,5 & 2 & 3,0 & 18 & 27,3 & 29 & 43,9 & 14 & 21,2 & 3,74 \\
\hline$\sum \times 2$ & 10 & 15,1 & 26 & 39,4 & 54 & 81,8 & 77 & $\begin{array}{c}116, \\
6\end{array}$ & 31 & 47 & \\
\hline $\begin{array}{c}\text { Competen } \\
\text { ce }\end{array}$ & 3 & 5,0 & 9 & 13,1 & 18 & 27,3 & 26 & 38,9 & 10 & 15,7 & 3,5 \\
\hline X3.1 & 2 & 3,0 & 0 & 0 & 10 & 15,2 & 36 & 54,5 & 18 & 27,3 & 4,03 \\
\hline $\mathrm{X} 3.2$ & 1 & 1,5 & 2 & 3,0 & 14 & 21,2 & 32 & 48,6 & 17 & 25,8 & 3,94 \\
\hline $\mathrm{X} 3.3$ & 10 & 15,2 & 15 & 22,7 & 11 & 16,7 & 19 & 28,8 & 11 & 16,7 & 3,09 \\
\hline $\mathrm{X} 3.4$ & 1 & 1,5 & 5 & 7,6 & 18 & 27,3 & 32 & 48,5 & 10 & 15,2 & 3,68 \\
\hline $\mathrm{X} 3.5$ & 1 & 1,5 & 4 & 6,1 & 7 & 10,6 & 27 & 40,9 & 27 & 40,9 & 4,14 \\
\hline$\sum X 3$ & 15 & 22,7 & 26 & 39,4 & 60 & 91 & 146 & 221 & 83 & 125,9 & \\
\hline \begin{tabular}{|l} 
Me \\
ani \\
ngf \\
ul \\
\end{tabular} & 3 & 4,5 & 5 & 7,9 & 12 & 18,2 & 29 & 44,3 & 17 & 25,2 & 3,8 \\
\hline $\mathrm{X} 4.1$ & 0 & 0 & 4 & 6,1 & 10 & 15,2 & 32 & 48,5 & 20 & 30,3 & 4,03 \\
\hline $\mathrm{X} 4.2$ & 3 & 4,5 & 0 & 0 & 10 & 15,2 & 24 & 36,4 & 29 & 43,9 & 4,15 \\
\hline Y1.4.3 & 2 & 3,0 & 6 & 9,1 & 16 & 24,2 & 32 & 48,5 & 10 & 15,2 & 3,64 \\
\hline $\mathrm{X} 4.4$ & 2 & 3,0 & 1 & 1,5 & 17 & 25,8 & 31 & 47,0 & 15 & 22,7 & 3,85 \\
\hline$\sum X 4$ & 7 & 10,5 & 11 & 16,7 & 53 & 80,4 & $11 \mathrm{~s}$ & $\begin{array}{c}180 \\
4\end{array}$ & 74 & 112,1 & \\
\hline $\begin{array}{l}\text { Pr } \\
\text { ogr } \\
\text { ers }\end{array}$ & 2 & 2,6 & 3 & 4,2 & 13 & 20,1 & 30 & 45,1 & 19 & 28,0 & 3,9 \\
\hline
\end{tabular}

SIntrinsic Motivation

\begin{tabular}{|l|l|l|l|l|l|l|l|l|l|l|}
\hline 3 & 4,7 & 6 & 8,1 & 14 & 20,8 & 30 & 45,0 & 14 & 21,5 & 3,7 \\
\hline
\end{tabular}

d. Progress is the perception that significant steps have been achieved toward accomplishing task goals. The following research hypotheses are based on the evolution of current theories:

H1: The option has a favorable and substantial influence on the decision-making process for Islamic stock investments.

H2: Competence has a favorable and substantial influence on the decision-making process regarding Islamic stock investments.

H3: Meaningful has a favorable and substantial influence on the decision-making process for Islamic stock investments.

H4: Progress has a favorable and vital impact on the decision-making process for Islamic stock investors.

\section{METHOD}

The sample for this research includes investors in Islamic equities in Central Kalimantan who are members of the Central Kalimantan Investor Community. Purposive sampling was utilized to collect the data. The questionnaire survey is used to ascertain investors' preferences for Islamic equities, which are impacted by the investors' characteristics. The surveys were issued in batches of 100 , with a response rate of 82 questionnaires, or 82 percent. This research employs a regression approach known as multiple regression. The study's dependent variable is intrinsic Motivation. The measures utilized in this research are based on Thomas's performance in [9], namely 1) option, 2) competence, 3) meaningful, 4) progress.

\section{RESULT AND DISCUSSION}

The average score for each indicator in Table 1 indicates that relevant indicators (X3) and Progress (X4) are rated highly by respondents with an average score of 3.8 .

Meanwhile, respondents rated choice (X1) and competence (X2) as modest, averaging 3.7 and 3.5 points, respectively. The description of respondents' views above demonstrates that respondents have a moderate to a high degree of intrinsic drive.

This finding indicates that respondents have a modest amount of intrinsic drive. Meaningfulness and Progress are essential indicators of the investment decisionmaking process. Meanwhile, choice and competence are intermediate or moderate factors influencing the respondent's intrinsic motivation level. 
Table 2. Multiple Regressions Of The Influence Of Investor Intrinsic Motivation On Islamic Stock Investment Decisions

\begin{tabular}{clllll}
\hline Model/Variable & $\begin{array}{l}\text { Adjust } \\
\text { ed } \boldsymbol{R} \\
\text { Square }\end{array}$ & $\boldsymbol{F}_{\text {sig }}$ & $\begin{array}{l}\text { Standar } \\
\text { dized } \\
\text { Coeffici } \\
\text { ents } \\
\text { Beta }\end{array}$ & Sig. & $\begin{array}{l}\text { Hypothese } \\
\text { s }\end{array}$ \\
\hline 1 & 0,762 & $\begin{array}{l}0,0 \\
0\end{array}$ & & & \\
Option $\left(\mathrm{X}_{1}\right)$ & & & 0,327 & $\begin{array}{l}0,00 \\
3\end{array}$ & accepted \\
Compet & & 0,405 & $\begin{array}{l}0,00 \\
2\end{array}$ & accepted \\
\hline ence (X) & & 0,235 & $\begin{array}{l}0,00 \\
0\end{array}$ & accepted \\
gful (X3) & & & 0,412 & $\begin{array}{l}0,00 \\
0\end{array}$ & accepted \\
\hline Progres & & & & & \\
\hline
\end{tabular}

On the basis of Table 2, the following regression equations may be generated:

$$
Y=0,327 X 1+0,405 X 2+0,235 X 3+0,425 X 4
$$

This research demonstrates that all investor intrinsic motivation characteristics affect the choice to invest in Islamic securities on the Indonesian stock market. Investors emphasize that decision-making is contingent upon their capacity to maintain a high degree of rationality in their investing choices.

\section{CONCLUSION}

This research demonstrates that all intrinsic motivation traits of choice, competence, meaningfulness, and advancement have a favorable and substantial effect on investors' investing decisions in Islamic equities. The implications of this study are likely to lead to the establishment of a personal literacy strategy by elucidating investors' underlying motivations and emphasizing the advantages of investing in Islamic companies on the Indonesian Stock Exchange.

\section{AUTHORS' CONTRIBUTIONS}

All authors fully contribute starting from the preparation of topics, research data, and review of research results

\section{ACKNOWLEDGMENT}

The author teams are grateful to CEL KODELN, ICESEBE Comitee and Makasar State University (UNM).

\section{REFERENCES}

[1] T. A. Gumanti, "Behavior Finance : Suatu Telaah," Usahawan, 2009.

[2] V. Ricciardi and H. K. Simon, "What is behavioral finance?," Business, Educ. Technol. J., vol. 2, no. 2, pp. 1-9, 2000.
[3] C. Kimeu, W. Anyango, and G. Rotich, "Behavioural factors influencing investment decisions among individual investors in Nairobi Securities Exchange," Strategy. J. Bus. Chang. Manag., vol. 3, no. 4, pp. 1244-1258, 2016.

[4] D. D. Gedmintiene and A. Visockaite, "The importance of personal finance for investment and applying financial behavior principles in personal finance investment decisions in Lithuania," Soc. Moksl. Stud., vol. 8, no. 1, 2016.

[5] M. Rahman and S. S. Gan, "Generation Y investment decision: an analysis using behavioral factors," Manag. Finance., 2020.

[6] S. Uslu Divanoğlu and D. BAĞCI, "Determining the factors affecting individual investors' behaviors," Int. J. Organ. Leadersh., vol. 7, pp. 284-299, 2018.

[7] J. M. Mathis, S. M. Belkoff, and H. Deramond, "Introduction: History and early development," in Percutaneous vertebroplasty, Springer, 2002, pp. $1-5$.

[8] C. L. Rahmi, "Pengaruh Risiko Kredit, Risiko Likuiditas Dan Risiko Tingkat Bunga Terhadap Profitabilitas (Studi Empiris pada Perusahaan Perbankan Terdaftar di Bursa Efek Indonesia)," J. Akunt., vol. 2, no. 3, 2014.

[9] K. Umam, Perilaku Organisasi. Bandung: CV Pustaka Satia, 2010.

[10] T. Schielke, "The language of lighting: applying semiotics in the evaluation of lighting design," Leukos, vol. 15, no. 2-3, pp. 227-248, 2019. 